\title{
Employee Burnout in Private University
}

\author{
Yayah Sutisnawati \\ Departemen of Magister Management \\ Universitas Komputer Indonesia Bandung, Indonesia \\ yayah.sutisnawati@email.unikom.ac.id
}

\author{
Deden Abdul Wahab Syahroni \\ Departemen of Magister Management \\ Universitas Komputer Indonesia Bandung, Indonesia \\ deden.syahroni@email.unikom.ac.id
}

\begin{abstract}
The aim of the research is to investigate how the extent the employee's burn out employees in Private University. The study case was conducted in this research by distributing questionnaires to 152 respondents in a Private University in Bandung. Quantitative method was used in this research with descriptive and verification analysis. Additionally, validity and reliability were performed on the questionnaire's data. SEM Analysis was performed to find the influence between employee's burnout and working performance. The result showed that the employee's burnout has a $12 \%$ significant influence on working performances. The routine work within a long period was indicated to become the main reason of this. The finding of the research contributes recommendation and data for the employment management, especially in university.
\end{abstract}

Keywords - employee's burnout, working performance, workload, private universities.

\section{INTRODUCTION}

In the digital era, competition among the universities has become tighter due to higher demand on academic quality [1]. Since the service quality is one of the crucial factor that determine the competitive advantage of the university, there is need a serious attention on employment management [2]. Burnout was found as a major problem in the employment management. Burnout is psychology condition due to long period of working stress exposure [3]. Another definition stated that burnout is emotional fatigue syndrome, depersonalization and a low sense of personal achievement that leads to reducing the effectiveness in the workplace [3]. In another words, Burn-out is defined as failure or exhaustion due to of excessive energy, strength, or resources demand [4]

There are prior researches stated that burn out syndrome has a strong relationship with longer working hours [4,5]. However, the research is not performed in the university. The research of Vandenberghe, Roland, and A. Michael Huberman, eds (1999) indicated that the burn out on teacher is highly influenced by environment condition and school setting as well [6]. Another research investigate burnout syndrome in personnel management in human service found that the burn out syndrome caused by perceived imbalance between demands and resources. Some employees feel exhausted because cannot fulfil the demands of competence from the company. Unfortunately, how extent the burn out syndrome did not explained in exact percentage $[7,8]$. Therefore, the comprehensive research concerning the employee's burn out syndrome in more specific area like university need to be performed.

The aims of the research is to investigate how extent the employee's burn out syndrome in the private university. The research was conducted in a private university in Bandung.
The distribution of questionnaires were conducted to 152 respondents and was given score by Likert scale. The method use is quantitative method by validity and reliability test. Descriptive analysis was also performed to explain the result of the research.

\section{METHOD}

The study case was conducted in a Private University in Bandung, Indonesia Computer University. The series of questionnaires were distributed to 152 respondent on June 26, 2018. The questionnaires covered 30 questions and was scored by Likert scale. The data of the questionnaires was analyzed by quantitative method. Validity and reliability test was performed on the data. SEM analysis also performed to measure the significance influence of burnout toward working performance.

The calculation of the correlation coefficient of Pearson should be performed for validity testing stage using the following formula: Results

$$
\begin{array}{ll} 
& \underline{\mathrm{n}\left(\sum \mathrm{XY}\right)-\left(\sum \mathrm{X}\right) \cdot\left(\sum \mathrm{Y}\right)} \\
\mathrm{rXy}= & \sqrt{ }\left\{\mathrm{n} \sum \mathrm{X} 2-\left(\sum \mathrm{X}\right) 2\right\} \cdot\left\{\mathrm{n} \sum \mathrm{Y} 2-\left(\sum \mathrm{Y}\right) 2\right. \\
\mathrm{X} & =\text { Total item score } \\
\mathrm{Y} & =\text { Amount of total score (all of item) } \\
\mathrm{n} & =\text { Number respondent }
\end{array}
$$

Criteria for decision-making

Criteria for decision making in testing validity are:

1. If $r$ count $>r$ table, then the statement is valid

2 . If $r$ count $<\mathrm{r}$ table, then the statement is invalid

The critical value of Pearson is $0,197 . \mathrm{r}$ count on all statements that all $\mathrm{r}$ count $>\mathrm{r}$ table so that the data is declared valid [9].

Furthermore, reliability testing (reliability level of the questionnaire) is calculated by using Cronbach Alpha formula $[9,10]$.

Several initial hypotheses can be arranged from research model as follows:

$\mathrm{H}_{0}: \rho_{1.2}=0$. Workload will not have a positive impact and significant toward burnout syndrome

Ha : $\rho_{1.2} \neq 0$. Workload will have a positive impact and significant toward burnout syndrome 


\section{RESULT AND DISCUSSION}

Table I explain that the data were declared valid. The critical value of Pearson is 0,197 . $r$ count on all statements $>r$ table [11].

TABLE I. The Result of Validity Test

\begin{tabular}{|c|c|c|c|}
\hline Statement & r statistic & Critical point & Conclusion \\
\hline x2.1 & 0,936 & 0,158 & Valid \\
\hline x2.2 & 0,919 & 0,158 & Valid \\
\hline x2.3 & 0,908 & 0,158 & Valid \\
\hline x2.4 & 0,925 & 0,158 & Valid \\
\hline x2.5 & 0,833 & 0,158 & Valid \\
\hline x2.6 & 0,895 & 0,158 & Valid \\
\hline x2.7 & 0,760 & 0,158 & Valid \\
\hline x2.8 & 0,881 & 0,158 & Valid \\
\hline x2.9 & 0,913 & 0,158 & Valid \\
\hline x2.10 & 0,835 & 0,158 & Valid \\
\hline x2.11 & 0,891 & 0,158 & \\
\hline
\end{tabular}

TABLE II. The result of reliability test

\begin{tabular}{|l|l|l|l|}
\hline Variable & $\begin{array}{l}\text { r } \\
\text { statistic }\end{array}$ & $\begin{array}{l}\text { Critical } \\
\text { point }\end{array}$ & Conclusion \\
\hline Burnout $(\mathrm{X} 2)$ & 0,959 & 0,7 & Reliable \\
\hline Working performance $(\mathrm{Y})$ & 0,748 & 0,7 & Reliable \\
\hline
\end{tabular}

Table II explain that all data were declared reliable based on Alpha Cronbach formula.

TABLE III. Recapitulation of Burnout Response

\begin{tabular}{|c|c|c|}
\hline Dimension & Score & Mean \\
\hline Emotional Exhaustion & 1710 & 2,81 \\
\hline Depersonalization & 1425 & 3,13 \\
\hline The decrease on individual achievement & 1875 & 3,36 \\
\hline Total and average & $\mathbf{5 0 1 0}$ & $\mathbf{3 , 1}$ \\
\hline
\end{tabular}

Table III explain about the score of Burnout response. Variables measured were emotional exhaustion, depersonalization, the decrease on individual achievement. Overall the processing results presented in the table produce a total score of 5010 with an average of 3.1. The mean value is entered into the continuum line, the measurement of which is determined in the following way:

- Maximum Index Value $=5$
- Minimum Index Value $=1$

- Interval distance $=[$ maximum value - minimum value $]: 5$

$$
\begin{aligned}
& =[5-1]: 5 \\
& =0.8
\end{aligned}
$$

- Overall average $=[($ total score $):$ (number of respondents $\mathrm{x}$ number of questions)]

$$
\begin{aligned}
& =[(5010):(152 \times 11)] \\
& =3.1
\end{aligned}
$$

\section{DISCUSSION}

Employee's burn out has significant influence toward the working performance; The result proves that the hypothesis Ha: $\rho_{1.2} \neq 0$ is acceptable, wherein t statistic 3.681 $>1.976$ t table. Correlation coefficient between employee's burn out and the working performance is 0.316 categorized weak/low. [9].

Table 2 showed that the burnout of the employee has significant influence toward working performance. This research confirmed the prior research concerning employee's burnout. However, the research was conducted on in hospital. Overall, high job stress rates affected nearly twothirds of psychiatric staff and one in five staff members suffered from fatigue. Psychiatrists and social workers report the highest level of fatigue, and support workers and psychologists, the lowest. The finding of this research is depict burnout in the university's employee. The similarity of the research, the employee's burnout is largely predicted by the frequency of higher face-to-face interactions with users, longer working hours, weak working group cohesion and perceived injustice [12]

Table 3 showed that employee's burnout (X2) has a significant influence on Working Performance (Y). Heavy workload, isolation at work, short-term funding and low salary were important barriers to pursuing a research career in primary care. The desire and opportunity to improve primary care, the flexible working conditions, the career opportunities, including the possibility of combining university-based research with clinical work and a friendly and competent research environment were important facilitators to attracting and retaining primary care researchers. Younger researchers were more concerned about short-term funding and job insecurity, and many of them were interested in a career combining clinical work and research. There were no clear differences between male and female researchers [13].

As depicted in table 4 burnout response covering three dimension such as emotional exhaustion, depersonalization and the decrease of individual achievement. This measured dimension in line with the definition of burnout. Burnout is the emotional fatigue syndrome, depersonalization and a low sense of personal achievement that leads to reducing the effectiveness of the workplace [5]. According to Maslach there are three components of burnout; Emotional fatigue, depersonalization, and a sense of lack of personal achievement [14]. Emotional fatigue which means energy discharge and consumption of emotional resources [15]. Depersonalization of the tendency to respond to others who are callous, separate, emotionally hardened. Uncaring and 
inhumane ways [16]. As depicted in figure 1 the employee's burnout was classified into 5 categories such as very not good, not good, fair, good, and very good.

$(3,1)$

\begin{tabular}{|c|c|c|c|c|}
\hline $\begin{array}{r}\text { Very } \\
\text { not good }\end{array}$ & $\begin{array}{c}\text { Not } \\
\text { good }\end{array}$ & Fair & Good & $\begin{array}{c}\text { Very } \\
\text { good }\end{array}$ \\
\hline 1 , & & & 2,60 & \\
\hline 3,40 & & & 5,00 & \\
\hline
\end{tabular}

TABLE IV. Average Continuum Line of Employee's Burnout

Table IV showed that the score obtained is 5010 with an average of 3.01. Therefore we can conclude that the respondent's response to burnout as a whole is in a good category [14]

Based on the results of questionnaires that have been carried out on three dimensions of burnout, namely: emotional fatigue, depersonalization, decreased individual achievement, has an average value of 3.1 in the good category. This proves that the employee of Indonesia Computer University as the case study were not experience burnout in terms on workload. Burnout is considered as a process used to indicate the conditions of mal-adjustment in the face of work stress experienced by workers in the service sector. In addition, burnout itself emphasizes the occurrence of a change in motivation and loss of enthusiasm experienced by employees related to disappointment in the work situation.

Freudenberger and Richelson (in Andarika, 2004) stated that there were 11 characteristics in patients with employee's burnout, namely: (1) Fatigue which is a process of energy loss accompanied by fatigue; Burnout sufferers experience physical fatigue which is characterized by feelings of lack of energy and feeling tired all the time. (2) Run from reality; Burnout sufferers tend to avoid work responsibilities and often skip work (3) Boredom and cynicism; caused by a less challenging task, lack of meaning and not diverse will cause a feeling of boredom that gave birth to a loss of interest in work and people in the work environment. (4) Impatient and irritable; Burnout sufferers tend to be more irritable and offended due to trivial matters, due to perceived tension. (5) Feeling only himself who can solve all problems; this is based on the growing feeling of being a superhuman, that is feeling able to handle something, not needing help so that it becomes high-hearted because of it. (6) Feeling unappreciated; this happens when the peak of individual ambition is too high, pushing himself too hard so that disagreement with reality triggers disappointment and feelings of disrespect. (7). Having disorientation; loss of direction and purpose of life do not know what the target of the job.(8) Psychosomatic complaints; Burnout sufferers often experience nausea headaches, back pain and other physical complaints that are not known what causes them. 9. Suspicion without reason; Burnout sufferers become easily suspicious of others because of the development of negative opinions in themselves that make them keep distance from others and stay away from the social environment. 10. Depression is a mood disorder, a prolonged emotional condition, which colors the whole process of thinking, feeling and behaving. 11. Denial; is a behavior of refusing to face unpleasant facts [17]

Emotional Exhaustion is a dimension of burnout condition which manifests as the deepest feeling and energy as a result of excessive psych emotional demands which are marked by (1) loss feelings and attention, trust, interest and passion. Employees who experience emotional exhaustion will feel their life empty, tired and unable to cope with the demands of their work (2) Depersonalization is a tendency of humanity towards fellow employees which is the development of a cynical attitude about career and self performance. People who experience depersonalization feel that none of their activities are valuable or valuable. This attitude is shown through indifferent behavior, being cynical, not feeling and not paying attention to the interests of others. (3) Reduction in Individual Achievement (Reduced Personal Accreditation) is an attribute of lack of self-actualization, low work motivation and decreased self-confidence. Often this condition refers to the tendency of individuals to evaluate themselves negatively in connection with the achievements they achieve. This is part of the development of depersonalization, negative attitudes and views of the client gradually lead to feelings of guilt in the service provider. Individuals will not feel satisfied with the results of their own work, feel they have never done something useful for themselves, or others. This feeling will develop into an assessment of oneself in fulfilling his responsibilities related to his work.

According to Mangkunegara (2000) states that factors that affect performance includes : a. Ability factor : Psychologically, the ability of employees consists of the ability of potential (IQ) and the ability of reality (education). Therefore, employees need to be placed in jobs that are in accordance with their expertise. b. Motivation Factors; Motivation is formed from the attitude (attitude) of an employee in dealing with work situations. Motivation is a condition that moves the employee self-directed towards achieving work goals. Mental attitude is a mental condition that encourages a person to try to achieve work potential to the fullest.

According to Gomes (2003) the criteria for developing performance that can be measured objectively for their development require certain qualifications. There are three important qualifications for developing performance criteria that can be measured objectively, namely: 1) Relevance, which is a measurement that shows the level of conformity between criteria and performance objectives. For example, the speed of production can be a performance measurement that is more relevant when compared to one's appearance. 2) Reliability, which is a measurement that shows the level at which criteria produce consistent results. Quantitative measures such as production units and sales volumes can produce relatively consistent measures. Whereas subjective criteria, such as attitude, creativity and cooperation produce measurements that are inconsistent because it depends on the person who evaluates it. 3) Discrimination, namely the level of measurement where a performance criterion can show differences in performance. If values tend to show all good or bad, this means that performance measures are not discriminatory, do not distinguish the performance of each worker.

The result of the research is contribute on the evaluation process of employee management. Judging from the 
effectiveness in the evaluation process, there are three different performance assessments, namely: 1) Result; based performance evaluation. Performance appraisal is based on the final results, namely the type of performance assessment carried out by formulating performance in achieving organizational goals and measuring the final results. 2) Behavioral-based performance evaluation. Assessment of work based on behavior, which is a type of performance assessment that intends to measure the achievement of goals (goals), and not the end result (end result). In practice, most jobs that cannot be measured are objective measures because they involve qualitative aspects. 3) Judgment-performance evaluation. Judgment based performance assessment, namely the type of performance assessment that assesses or evaluates workers' performance based on specific behavioral descriptions such as quantity of work, quality of work, job knowledge, corporation, initiative, reliability, interpersonal competence, loyalty, dependability, personal qualities, and the like [19]

\section{CONCLUSION}

The employee's burnout (X2) has a significant influence on Working Performance (Y). To prevent employee's burnout the university management must be able to pay attention to the need of the employees. Several program to overcome the employee's burnout is Recreation and Work Rotation. Through the entertainment program and work rotation, it is expected that employees will not be bored at work. The quality of human resources is an important factor that supports rapid development of the university. This research is contribute to provide data for human resource management in the university.

\section{ACKNOWLEDGMENT}

We would like to acknowledge Universitas Komputer Indonesia to support the fund of the research.

\section{REFERENCES}

[1] G. Hanna, Donald E. (1998) "Higher education in an era of digital competition: Emerging organizational models." Journal of Asynchronous Learning Networks 2.1: 66-95.

[2] Halbesleben, Jonathon RB, and M. Ronald Buckley. (2004) "Burnout in organizational life." Journal of management 30.6: 859879.]

[1] 4 Freudenberger, Herbert J. (1975) "The staff burn-out syndrome in alternative institutions." Psychotherapy: Theory, Research \& Practice 12.1: 73 .
[2] 5 Maslach, Christina, and Ayala Pines. (1977) "The burn-out syndrome in the day care setting." Child care quarterly 6.2: 100113.

[3] 6. Vandenberghe, Roland, and A. Michael Huberman, eds. 1999. Understanding and preventing teacher burnout: A sourcebook of international research and practice. Cambridge University Press.

[4] 7 Cherniss, Cary. 1980.Staff burnout: Job stress in the human services. Beverly Hills, CA: Sage Publications.

[5] 8. Maslach, Christina, Wilmar B. Schaufeli, and Michael P. Leiter. (2001)"Job burnout." Annual review of psychology 52.1: 397-422.

[6] Embriaco, Nathalie, et al. (2007)"Burnout syndrome among critical care healthcare workers." Current opinion in critical care 13.5: 482-488.

[7] R Kothari and G Garg, 2014. Research Methodology Methods and Techniques $3^{\text {rd }}$. New Age International (P) Limited, Publishers. New Delhi.

[10] Castillo R, Who is Slovin and where and how did the Slovin's Formula for determining the sample size for a survey research originated?

[11] Linn, Robert L. (1983) "Pearson selection formulas: Implications for studies of predictive bias and estimates of educational effects in selected samples." Journal of Educational Measurement 20.1: 115.

[12] Yoleri, sibel, and m. ömer bostanci. (2012)"determining the factors that affect burnout and job satisfaction among academicians: a sample application on the hitit university." Electronic Turkish Studies 7.4.

[13] González-Romá, Vicente, et al.(2006)"Burnout and work engagement: Independent factors or opposite poles?." Journal of vocational behavior 68.1: 165-174.

[14] Maslach, Christina, Wilmar B. Schaufeli, and Michael P. Leiter. (2001)"Job burnout." Annual review of psychology 52.1: 397-422.

[15] Leiter, Michael P., and Christina Maslach. 2005.Banishing burnout: Six strategies for improving your relationship with work. John Wiley \& Sons.

[16] Maslach, Christina, and Susan E. Jackson. (1981) "The measurement of experienced burnout." Journal of organizational behavior 2.2: 99-113.

[17] Andarika, Rita. (2004) "Burnout Pada Perawat Puteri RS St. Elizabeth Semarang Ditinjau Dari Dukungan Sosial." Jurnal Psyche 1.1: 1-8.

[18] Maslach \& Jackson S.E. 1981. The Measurement of Exsperienced burnout; journal of accupational behavior.2, 99-133.

[19] Gomes, Faustino Cardoso.2003. Manajemen Sumber Daya Manusia. Yogyakarta; Penerbit Andi. 